\title{
Mengungkap Kebenaran Pelanggaran Berat HAM Masa Lalu di Era Transisi Demokrasi
}

\author{
Suparman Marzuki
}

The problem of state responsibility toward gross violation of human rights that conducted by past regime denotes and becomes a crucial and complex problem including the gross violation of human rights that happening in Indonesia. In term of this, for instances the cases of Tanjung Priok, Komando Jihad, Aceh, Talang Sari Lampung and so on. Because of the fall of New Order Regime, pro democracy powers as like South Africa, East Europe, The Latin America and Asia countries force to settle tha cases of human rights as prerequisite of democracy consolidation. According to author of the article that the responsibility of gross violation of human rights by past regime denotes an agenda for each transitional government because there are rights to know the truth, rights of justice, and rights to human dignity. The task of the regime is preparing the mechanism how to responsible for old regime.

Kata kunci: HAM, transisi, penegakan hukum

rihal tanggungjawab negara (state re sponsibility) baru atas sejumlah pelanggaran berat hak asasi manusia (gross violation of human rights) yang dilakukan rezim masa lalu menjadi salah satu isu sangat pelik bagi masyarakat yang baru lepas dari rezim otoritarian, termasuk yang terjadi di Indonesia. Masyarakat Indonesia yang berada di bawah kekuasaan rezim totaliter mengalami masa-masa sulit dan kejam. Mereka disiksa, dihilangkan, dibunuh, diancam, diintimidasi secara sewenang-wenang. Kasus Tanjung Priok, Komando Jihad, Penembakan Misterius (petrus), Aceh, Talang Sari Lampung, Papua, Kasus Semanggi 1 dan Semanggi 2, penghilangan paksa terhadap mahasiswa, dan sebagainya adalah contoh- contoh kasus yang terjadi selama rezim Orde Baru. Kekejaman-kekejaman itu dilakukan untuk dan atas nama kepentingan "pembangunan", "stabilitas politik", "ekstrim kanan", "ekstrim kiri", dan seterusnya. ${ }^{1}$

Ketika rezim Orde Baru tumbang, kekuatan-kekuatan pro demokrasi, sebagaimana di Afrika Selatan, Eropa Timur, Amerika Latin dan Asia (khususnya Filipina) mendesak rezim baru agar pelbagai kasus pelanggaran HAM berat itu diagendakan untuk diselesaikan lebih dahulu sebagai prasyarat konsolidasi demokrasi. Mereka

${ }^{1}$ Operasi-operasi pemberangusan yang kejam itu pada rezim otoriter selalu dilakukan oleh satuan-satuan khusus. Di Argentina misalnya, ketika di bawah rezim junta militer,satuan khusus ini diberi nama "pasukan pembunuh" dan telah membunuh lebih dari 10.000 orang yang dikenal dengan "Dirty War." 
mendesak pemerintahan baru bertanggungjawab atas pelanggaran berat hak asasi manusia (gross violation of human rights) yang dilakukan rezim sebelumnya karena telah menjadi hutang pertangganggungjawaban yang belum dibayar oleh rezim otoriter itu. Sekaranglah saatnya pertanggungjawaban terhadap masa lalu itu ditagih.Tetapi disinilah letak masalahnya, pertanggungjawaban atas masa lalu itu ternyata tidak semudah memperdengarkannya. Realitas politik terbukti tidak sepenuhnya memberi ruang terbuka bagi upaya semacam itu meski berada pada "ruang" kekuasaan rezim baru.

Pro kontra atas itu menjadi tidak terhindarkan. Apakah menyelesaikannya dengan mengajukan ke pengadilan (to punish)?, dengan cara melupakannya (to forget)?, atau memaafkannya (to pardon)? Sebagian kalangan (sejumlah Jenderal dan pimpinan politik) mempertanyakan untuk apa pelanggaran berat HAM masa lalu itu diungkit-ungkit? Apa tidak justeru menciptakan kebencian lebih dalam, memperburuk keadaan, dan berbahaya bagi masa depan? Apa tidak lebih baik, kita luruskan pandangan ke depan, tidak menoleh ke belakang demi hari depan itu sendiri' ${ }^{2}$ ?

Kalangan kekuatan pro demokrasi tentu berpendapat sebaliknya. Mereka tegas menyatakan bahwa tidak mungkin membiarkan kejahatan terhadap kemanusian berlalu begitu saja tanpa pertanggungjawaban. Mengungkap dan meminta . pertanggungjawaban kekejaman rezim masa lalu adalah mengungkap kebenaran dan pertanggungjawaban sejarah, karena sejarah bukanlah masa lalu, tetapi proses pemikiran yang menjadi rangkaian tidak terputus bagi masa depan. Tidak mungkin membangun hari depan yang lebih baik di atas pondasi kebohongan yang disadari.
Sangat disadari bahwa setiap pemerintahan transisi, tidak terkecuali Indonesia, dihadapkan pada kesulitan untuk menangani masa laiunya yang penuh ketidakadilan itu dengan tandas. Kebanyakan dari pemerintahan transisi menghadapi dilema yang disebut oleh Dianne Orentlicher ${ }^{3}$ sebagai "Hobson's choice", yaitu suatu dilema memilih antara kelangsungan hidup pemerintahan baru itu dengan prinsip-prinsip yang melandasi eksistensi dirinya yang harus pula ditegakkan. Dilema itu juga menggambarkan betapa rapuhnya rezimrezim transisional, terutama rezim-rezim baru yang lahir dari proses politik yang dinegosiasikan, seperti tampak pada kasus Afrika Selatan atau Uruguay. Di Afrika Selatan misalnya, perundingkan tidak hanya format politik yang akan dibangun tetapi juga bagaimana menyelesaikan pelanggaran berat HAM yang dilakukan rezim apartheid. Hasilnya adalah diberikannya amnesty bagi mereka yang berasalah di masa lalu. Proses yang hampir sama terjadi juga di Uruguay; pemerintahan baru memberikan jaminan kepada militer yang menjadi pelaku utama pelanggaran berat HAM bahwa tidak akan ada proses hukum melalui apa yang dikenal dengan Naval Agreement. ${ }^{4}$

2 Menanggapi pandangan ini, Pejabat Deplu Amerika Serikat menyimpulkan, "ada keinginan untuk membersihkan luka-luka dari semua infeksi lama, sebelum penyembuhan dimulai". Lihat Priscilla B. Hayner Mencari akar dan Pandangan Bersama, Studi Banding Lima Belas Komisi Kebenaran di Berbagai Negara (terjemahan), ELSAM, 2002, hal. 26

${ }^{3}$ Dianne F. Orentlicher, "Setting Accoubts: the Duty to Prosecute Human Rights Violation of A Prior Regime", The Yale Law Journal, Vol.100

${ }^{4}$ Robert K. Goldman,Amnesty Laws and International Law: A Specific Case (International Commission of Jurist,Prosiding,1993, hal.209-222 
Agak berbeda dengan rezim baru yang lahir dari perlawanan rakyat. Di Yunani misalnya, pemerintahan yang lahir melalui mekanisme pemilihan umum (bukan negosiasi politik) yang demokratis, Perdana Menteri Constantine Karamanlis dengan dukungan penuh rakyatnya melakukan langkah-langkah hukum yang cepat dan berani.Dalam sembilan bulan kekuasaannya, Karamanlis berhasil menyeret dan menghukum para tentara melalui proses peradilan dan menyatakan mereka bersalah melakukan penghianatan tingkat tinggi, dan hasilnya sangat positif karena isu ketidakadilan masa lalu tidak lagi menjadi perbincangan dan tuntutan dalam dinamika politik Yunani. ${ }^{5}$ Tetapi apa yang terjadi di Yunani itu hanyalah salah satu contoh kasus model pilihan penyelesaian yang relatif berhasil, karena di negara transisional yang lain upaya serupa justru dihindari. Itu artinya bahwa pilihan-pilihan kebijakan, tidak bisa dilepaskan dari konteks transisi politik yang dihadapi masing-masing negara transisional tersebut.

Tulisan ini akan coba mendiskusikan soal yang amat pelik itu, khususnya dalam konteks kita yang baru tujuh tahun lepas dari cengkraman Orde Baru. Apa yang akan kita lakukan? Untuk itu tulisan ini akan diawali dengan diskusi teoritis sekitar langkah-langkah penyelesaian pelanggaran berat hak asasi manusia, lalu melihat peluang penyelesaian seperti apa yang paling realistis dapat dilakukan.

\section{Mekanisme Penyelesaian}

Ada berbagai macam bentuk strategi yang dipakai di berbagai negara di dunia dalam menangani pelanggaran HAM masa lalu, mulai dari mengadili secara massal pendukung orde terdahulu sampai "menutup buku" tanpa syarat. Di Prancis misalnya, pernah terjadi "peradilan Rakyat" terhadap keluarga kerajaan Louis XIV atau akhir abad ke 20 pengadilan rakyat atas 'keluarga Presiden Nicola Ceausecu di Rumania,dan yang terakhir pengadilan rakyat atas rezim Kabul dimana rakyat membunuh dan menggantung jasad Najibullah di tiang lampu jalan di sebuah jalan utama di kota Kabul Afganistan. Para demokrat Spanyol setelah kematian Franco memilih untuk tidak melakukan apa-apa, tanpa pengadilan dan penyelesaian lainnya. Di Republik Ceko dikeluarkan undang-undang "lustrasi". Di Hungaria, undang-undang serupa dikeluarkan, namun cakupannya dibatasi dan tidak dijalankan dengan konsisten. Di Argentina, setelah jatuhnya rezim militer, pemerintah baru mengadili sembilan petinggi militer yang dianggap paling bertanggungjawab. $D i$ Chili, lebih dari seperempat abad setelah kudeta terjadi, hanya satu komandan tinggi rezim Pinochet yang diadili. ${ }^{6}$

Proses legal yang berhasil membawa para pelaku kejahatan masa lalu ke pengadilan, selama dan setelah pemerintahan transisi sangat penting artinya karena proses ini mempunyai peran besar dalam menghilangkan praktik kekebalan hukum (impunity) atau "perlakuan istimewa" lainnya yang sebelumnya selalu dinikmati oleh para pemimpin negara dan aparat negara tingkat tinggi yang melanggar HAM di masa lalu. ${ }^{7}$ Menurut argumen di atas, pengadilan sebagai proses legal untuk mengakhiri praktik "impunity" telah menjadi syarat utama keberhasilan dalam menjunjung tinggi keadilan di masa yang akan datang.

Rezim baru atau demokrasi baru membutuhkan legitimasi sebagai dasar

5. Lihat laporan Amnesty International, "Torture in Greece: The First Torture's Trial, 1975, London, Amnesty International, 1977.

6. Untuk keterangan lebih lanjut dari contoh-contoh ini, lihat Martin Meredith, Coming to Terms, New York: Public Affairs, 1999 
stabilitas politik. Pengadilan dinilai banyak praktisi legal sebagai hal yang penting untuk menunjukkan supremasi nilai-nilai dan norma-norma demokrasi agar kepercayaan rakyat dapat diraih. ${ }^{8}$ Kegagalan mengadili, sebaliknya, dapat menyebabkan sinisme dan ketidakpercayaan rakyat terhadap sistem politik. Sejumlah analis percaya bahwa pengadilan dapat meningkatkan konsolidasi demokrasi jangka panjang. Salah satu argumennya yaitu bahwa jika tidak ada kejahatan yang diselidiki dan diadili, maka tidak akan tumbuh rasa percaya maupun norma demokrasi dalam masyarakat, dan karena itu tidak akan ada konsolidasi demokrasi yang sesungguhnya. ${ }^{9}$

Pokok soal yang umumnya menghantui gagasan mengungkap pelanggaran HAM masa lalu adalah bayang-bayang kegagalan, lebih-lebih sempat menjadi kenyataan di beberapa Negara, seperti yang terjadi di Uganda, Filipina dan seterusnya. Namun demikian, kesadaran pentingnya mengusut, mengungkap kebenaran dan meminta pertanggungjawaban tetap mengemuka sebagai jalan menuju demokrasi. Tidak mungkin sebuah bangsa dapat hidup bersatu padu dalam damai di atas sejarah penuh luka dan kekerasan. Proses transisi menuju demokrasi harus berjalan di atas proses sejarah yang jujur dan bertanggung jawab? Pemerintahan yang baru harus menemukan jalan keluar untuk meneruskan detak nadi kehidupan, menciptakan ulang ruang nasional yang damai dan layak dihuni, membangun semangat dan upaya rekonsiliasi dengan para musuh masa lampau, dan mengurung kekejaman masa lampau dalam sangkar masa lampaunya sendiri. ${ }^{10}$

Persoalannya apa yang harus dan dapat dilakukan masyarakat dan kekuasaan yang menggantikan dalam menghadapi kejahatan berat kemanusian masa lalu, jika masa lalu itu diliputi "kabut hitam"? Dapatkah ia diselesaikan melalui prosedur hukum formal yang prosedural, birokratis dan normatif, yang menuntut ketersediaan bukti-bukti formal dan meterial? Dapatkah hakim berdiri tegak bekerja dalam tekanan rezim atau agen-agen rezim masa lalu, demi hukum dan keadilan mengingat resistensi rezim masa lalu terhadap setiap upaya pengungkapan kejahatan yang pernah mereka lakukan di masa lalu itu cukup potensial. Para pemimpin militer yang merasa terancam oleh pengadilan mungkin berusaha merubah keadaan dengan sebuah kudeta, pemberontakan, ancaman atau konfrontasi lain yang akan melemahkan kekuasaan dari pemerintahan sipi.." Dalam kondisi ini, pengadilan akhirnya justru bisa

7. Banyaknya kekejaman di masa lalu yang dibiarkan berlàlu tanpa kelanjutan proses hukum, yang telah menyebabkan hilangnya kepercayaan masyarakat terhadap sistem hukum, dan mengancam sistem sosial masyarakat.

8. Samuel Huntington, Third Wave: Democratization in the late Twentieth Century, University of Oklahoma Press, 1991, hal 114124 Op.cit, hal 213

9. Lihat Laurence Whitehead, "The Consolidation of Fragile Democracies" in Robert Pastor, ed, Democracies in the Americas: Stopping the pendulum, New York:Holmes and Meier, 1989, hal 84

10. Lihat Ifdal Kasim, dkk (ed), Setelah Otoritarianisme Berlalu Esai-Esai Keadilan di Masa Transisi, ELSAM;2001, hal. Vi,

11. Banyak orang indonesia menganggap bahwa konflik yang terjadi di Aceh, Papua, Maluku, Kalimantan dan bagian-bagian Indonesia lainnya diciptakan oleh aktor-aktor tertentu, terutama dari militer, yang merupakan bagian dari rezim otoriter Soeharto yang ditujukan untuk melemahkan rezim baru atau setidak-tidaknya untuk mengalihkan fokus untuk tidak membicarakan pelanggaran berat HAM di masa lalu. 
memperkuat kecenderungan militer menantang institusi demokrasi. ${ }^{\text {t2 }}$

Mekanisme legal sebagai alternatif penyelesaian ternyata memiliki sejumlah keterbatasan. ${ }^{13}$ Pertama, persyaratan buktibukti legal untuk suatu proses hukum sulit dipenuhi karena pada umumnya alat-alat bukti sudah lenyap atau sengaja dilenyapkan. Kedua, para korban atau saksi takut mengambiul resiko memberikan kesaksian. Ketiga, lembaga peradilan pada umumnya lemah dan tidak dipercaya, terutama lembaga peradilan yang pernah menjadi instrumen rezim otoritarian sebelumnya, keempat, instrumen hukum yang tersedia tidak cakup mampu menjaring kejahatan negara terorganisir, karena konstruksi pasalpasal dalam hukum publik lebih pada kejahatan-kejahatan individual, dan Keempat, anggota militer, sisa-sisa kekuatan orde otoritarian, termasuk birokrasi sipil yang pernah menjadi bagian dari kejahatan kemanusiaan masa lalu secara terbuka atau rahasia menentang dan mengancam setiap proses hukum yang akan mengungkap kejahatan rezim masa lalu itu.

\section{Komisi Kebenaran dan Rekonsiliasi ${ }^{14}$}

Kesulitan dan kekhawatiran tidak bisa bekerjanya proses hukum formal menangani kejahatan kemanusiaan masa lalu, sebagaimana diungkap di atas menjadi dorongan kuat perlunya mekanisme lain, atau model penyelesaian alternatif, yang kemudian secara umum dikenal dengan "komisi kebenaran dan rekonsiliasi". Model penyelesaian alternatif ini sesungguhnya, bukan lawan dari penyelesaian hukum, tetapi "teman" dari penyelesaian hukum, meskipun memiliki mekanisme dan hasil akhir yang bisa berbeda. Komisi kebenaran kata Priscilla konsen pada penyelidikan masa Jampau, tidak dipusatkan pada kasus tertentu, melainkan sebagai upaya

12. Lihat penjelasan Tina Rosenberg mengenai keadaan Argentina, catatan penutup dalam Martin Meredith, op. cit. hal 329 : "...Besides trying the top junta members, Argentina sought to prosecute lower-ranking military officers responsible for crimes. But when the military began to grumble in a country that had already seen eleven military coups in this century, President Raul Alfonsin blinked. He proposed a law setting a date for an end to indictments, and another law that gave amnesty to middle and junior officers on the grounds that they were following orders." Lihat juga, antara lain, artikel Diane Orentlicher: "Setting Accounts: The duty to Prosecute Human Rights Violations of a Prior Regimen" in 100 Yale Law Journal, 1991

13. Pengadilan Nurenberg dan Tokyo yang mengadili tentara Nazi Jerman dan pelaku kejahatan PD. II dikatakan sebagai pengadilan penyelesaian secara tuntas pertanggungjawaban kejahatan kemanusian, tetap tetap dirktik tidak memenuhi rasa keadilan korban. Begitu pula dengan peradilan terhadap pemerintahan Vichy di Prancis yang memakan waktu puluhan tahun malah menimbulkan antipati rakyat Prancis yang didera kebosanan.

14. Tidak ada satu defenisi yang diterima secara umum tentang apa itu KKR. la (KKR) merupakan penamaan umum terhadap komisi-komisi yang dibentuk pada situasi transisi politik dalam rangka menangani pelanggaran berat atau kejahatan HAM di masa lalu. Hingga kini terdapat tidak kurang 20 KKR di berbagai Negara. Masing-masing komisi ini mempunyai nama, mandat, dan wewenang yang berbeda-beda satu dengan lainnya. Meski demikian, terdapat lima elemen yang dapat dikatakan sebagai karakter umum KKR, yaitu: (1) focus penyelidikannya pada kejahatan masa lalu, (2) tujuannya adalah mendapatkan gambaran ynag komprehensif mengenai kejahatan HAM dan pelanggaran hukum internasional pada suatu kurun waktu tertentu, dan tidak memfokuskan pada suatu kasus, (3) keberadaannya adalah untuk jangka 
melukiskan seluruh pelanggaran HAM atau pelanggaran terhadap hukum humaniter internasional selama satu periode tertentu, dibentuk dalam waktu sementara dan selama satu periode yang telah ditentukan sebelumnya, dan memperoleh beberapa jenis kewenangan.

Ide dasar dari konsep Komisi Kebenaran dan Rekonsiliasi didasarkan pada kepercayaan bahwa rekonsiliasi antara pelaku dan korban pelanggaran HAM membutuhkan pengungkapan kebenaran di belakang semua kejadian secara menyeluruh. 'Memberikan kesempatan kepada korban untuk bicara dan menerima penjelasan tentang kejadian-kejadian penting yang berhubungan dengan pelanggaran HAM di masa lalu' adalah hal yang penting. Karenanya, diharapkan hal ini dapat meletakkan pondasi untuk terungkapnya kebenaran demi tegaknya keadilan, yang pada gilirannya tercapai rekonsiliasi. ${ }^{15}$ Masalah ini sangat penting karena keadilan transisional lebih dari sekedar menangani pelanggaran HAM kasus per kasus, melainkan merupakan dasar moral sebuah reformasi pemerintahan dan masyarakat yang menghormati martabat manusia melalui cara-cara yang demokratis, non-kekerasan dan sesuai dengan prinsip supremasi hukum. Ini semua bertujuan agar kesalahan yang sama tidak terjadi lagi di masa yang akan datang. ${ }^{16}$

Dullah Omar, ${ }^{17}$ dalam pengantar penyampaian RUU tentang Komisi Kebenaran dan Rekonsiliasi di Afrika Selatan di depan parlemen, mengatakan,

"setelah melihat momok masa lalu di depan mata, dan setelah meminta dan menerima pengampunan serta melakukan penyesuaian, mari kita menutup pintu masa lalu bukan untuk melupakan, tetapi supaya jangan terjebak olehnya. Mari kita melangkah ke masa depan yang cemerlang, menjadi masyarakat baru dimana warganya dihargai bukan karena sifatsifat biologisnya atau sifat-sifat luar lainnya, tetapi karena mereka adalah manusia bermartabat yang diciptakan dalam citra ALLAH. Mari berharap bahwa masyarakat kita akan menjadi masyarakat yang benar"benar baru, lebih saling mengasihi, lebih saling memperhatikan, lebih lembut dan lebih mau berbagi, karena kita telah mengucapkan selamat tinggal kepada "masyarakat lama yang terpecah belah oleh perseteruan, konflik, penderitaan,

waktu tertentu, biasanya berakhir setelah laporan akhirnya selesai dikerjakan, (4) la memiliki kewenangan untuk mengakses informasi ke lembaga apa pun, dan mengajukan perlindungan untuk mereka yang memberikan kesaksian, dan (5) dibentuk secara resmi oleh Negara baik melalui Keputusan Presiden atau melalui UndangUndang, atau bahkan oleh PBB (Lihat Priscilla B. Ibid, hal. 8)

15. Ada banyak kekelirian tafsir atas KKR, bahwa KKR seolah-olah mengedepankan Rekonsiliasi, padahal yang utama dan diutamakan dalam KKR adalah mengungkapkan kebenaran demi kebenaran itu sendiri dalam rangka memberikan keadilan bagi korban. Kebenaran yang terungkap dan keadilan yang diberikan adalah jalan masuk bagi terciptanya rekonsiliasi.

16. Dalam pandangan Enny Soeprapto, upaya penyelesaian pelanggaran . HAM masa lalu melalui suatu komisi kebenaran dan rekonsiliasi (KKR) merupakan salah satu bentuk upaya perwujudan transitional justice (makalah, "pokok-pokok paparan disampaikan dalam pertemuan dan diskusi terbatas dengan tema penyelesaian masalah bangsa melalui komisi kebenaran dan rekonsiliasi yang diselenggarakan oleh lembaga kajian demokrasi (LKade), Jakarta, 5/12/03)

17. Karlina Laksono, Kompas, 19/8/2003 
konflik, penderitaan, dan ketidakadilan yang tidak terkira dan kini sedang menuju ke masa depan yang dibangun di atas pengakuan terhadap HAM, demokrasi dan eksistensi bersama secara damai dan peluang untuk menikmati pembangunan bagi seluruh warga Afrika Selatan, tanpa memandang warna kulit, ras, agama, dan kelamin."

Senada dengan Dullah Umar, dalam dengar pendapat tentang HAM dengan Uskup Desmon Tutu di Port Elizabeth, Afrika Selatan, seorang saksi mengajukan interupsi,

“Terimakasih Bapa Uskup, tetapi maaf ada satu hal yang ingin saya tanyakan. Mohon jaingan salah paham Bapa Uskup, anda tidak dapat berdamai dengan seseorang yang tidak datang kepada anda dan mengatakan apa yang telah dilakukannya. Kita hanya bisa berdamai jika seseorang datang kepada anda dan mengatakan: "inilah yang saya lakukan". Saya telah melakukan ini dan itu. Kalau mereka tidak datang kepada anda dan saya tidak tahu siapa mereka , bagaimana kami bisa berdamai. Tetapi, kini saya akan memaafkan mereka yang telah datang dan mengungkapkan perbuatannya. Inilah kebenaran itu. Kami beranggapan mereka yang mendengar dan mereka yang datang ke komisi juga akan tersentuh hatinya. Hati nurani mereka akan mengusik bahwa jika mereka ingin mendapatkan pengampunan, mereka sebaiknya datang dan secara terbuka mengungkapkan isi hatinya sehingga mereka juga bisa mendapatkan penyembuhan seperti yang dialami oleh para korban lainnya."18

Komisi Kebenaran tidak bisa dan tidak boleh menggantikan fungsi pengadilan, karena mereka bukan badan peradilan, mereka bukan persidangan hukum, dan mereka tidak memiliki kekuasaan untuk mengirim seseorang ke penjara atau memvonis seseorang karena suatu kejahatan tertentu. Hanya saja, Komisi Kebenaran dapat melakukan beberapa hal penting yang secara umum tidak dapat dicapai melalui proses penuntutanpersidangan di pengadilan pidana.

Komisi Kebenaran dapat menangani kasus dalam jumlah relatif lebih besar dibandingkan dengan Pengadilan pidana. Dalam suatu situasi dimana terjadi pelanggaran HAM berat yang meluas dan sistematis dibawah rezim sebelumnya, Komisi Kebenaran dapat menyelidiki semua kasus-kasus atau sejumlah besar kasus yang ada secara komprehensif dan tidak dibatasi kepada penanganan sejumlah kecil kasus saja. Komisi Kebenaran juga berada dalam posisi untuk menyediakan bantuan praktis bagi para korban dengan secara spesifik mengidentifikasi dan membuktikan individu-individu atau keluarga-keluarga mana saja yang menjadi korban kejahatan masa lampau sehingga mereka secara

18. Ibid

18. Contohnya, Komisi Kebenaran di Chile mengidentifikasi masing-masing orang dan anggota keluarga yang kemudian menjadi layak untuk berbagai fasilitas dari pemerintah di masa yang akan datang, seperti beasiswa sekolah, subsidi perumahan, asuransi kesehatan, dan pensiun. Untuk penjelasan lebih lanjut mengenai peraturan tentang kompensasi dan rehabilitasi di Chile, lihat Summary of the Truth and Reconciliation Report, Komisi Hak Asasi Manusia / Centro IDEAS, Departemen Luar Negeri Chile. Untuk informasi yang terperinci, tersedia di Report of the Chilean National Commission on Truth and Reconciliation, dapat diakses melalui website www. Derechoschile.com/ English_resour.htm\#rettig. 
hukum berhak untuk mendapatkan bentuk reparasi di masa yang akan datang. ${ }^{19}$

Komisi Kebenaran juga dapat dipakai untuk mencoba menjawab pertanyaanpertanyaan besar seperti; bagaimana sebuah pelanggaran HAM terjadi; Kenapa itu terjadi dan faktor apakah yang terdapat dalam masyarakat dan negara kita yang memungkinkan kejadian tersebut terjadi; perubahan-perubahan apa saja yang kita harus lakukan untuk mencegah tindakan kekerasan dan pelanggaran HAM tidak terulang kembali; dan sebagainya.

Terlebih lagi Komisi Kebenaran dapat membantu terlaksananya semacam resolusi dengan mengakui penderitaan yang dialami korban, membuat pemetaan atas pengaruh dari kejahatan di masa lalu, dan merekomendasikan reparasi. Komisi Kebenaran juga dapat merekomendasikan pembaharuan-pembaharuan tertentu di dalam institusi-institusi publik, seperti di dalam kepolisian dan pengadilan dengan tujuan mencegah terulangnya kembali pelanggaran hak asasi manusia. Terakhir, Komisi Kebenaran dapat memilah antara persoalanpersoalan pertanggung-jawaban dan mengungkapkan siapa pelaku-pelakunya ${ }^{20}$ Selain itu, Komisi Kebenaran dapat mengurangi jumlah kebohongan yang beredar tanpa dibuktikan kebenarannya di depan publik. Di Argentina, pekerjaan Komisi membuat militer mustahil mengklaim bahwa mereka tidak membuang korban yang setengah mati dari helicopter ke laut. Di Cile, di depan publik orang tidak boleh mengatakan, rezim Pinochet tidak membunuh ribuan orang tidak bersalah. ${ }^{21}$.

Dari sejumlah Negara yang pernah memiliki KKR seperti Argentina, Chili, Rumania, Jerman, Cekoslovakia, El Salvador, Guetemala, Afrika Selatan,Uganda, Filipina, dan lain sebagainya maka KKR Afrika
Selatan dinilai oleh banyak kalangan sebagai capaian terbaik penyelesaian pelanggaran berat hak asasi manusia masa lampau dengan menempatkan kepentingan korban sebagai titik tolak utama. Selain itu pengungkapan kebenaran dan rekonsiliasi berlangsung dalam proses yang sama ${ }^{22}$, dan pengampunan merupakan bagian dari rancangan awal.

\section{Konteks Indonesia}

Desakan untuk menyelesaikan pelanggaran berat hak asasi manusia di Indonesia sudah dimintakan pertanggungjawabannya semenjak pemerintahan B.J. Habiebie, Gus Dur, dan Megawati. Desakan tersebut banyak diajukan kepada Komisi Nasional Hak Asasi Manusia (Komnas HAM) yang dibentuk dengan Keputusan Presiden No.50 Tahun 1993, yang kemudian ditetapkan dengan UU No.39 Tahun 1999 tentang HAM. Beberapa diantaranya telah diselidiki dan ditindaklanjuti dengan diajukannya beberapa terdakwa ke pengadilan seperti kasus pelanggaran HAM Tanjung Priuk dan Timor Timur. Sayangnya, proses dan putusan yang dihasilkan belum dapat memenuhi rasa keadilan masyarakat, terlebih lagi keadilan bagi korban. Sejumlah kasus yang telah direkomendasikan oleh Komnas HAM bahkan belum ditindaklanjuti secara hukum, termasuk ratusan kasus yang sama sekali belum diselidiki.

Pendek kata upaya meminta pertanggungjawaban negara di era tiga presidẹn

${ }^{20}$ Karlina Laksono, Ibid

${ }^{21}$ Thomas Sunaryo, Hukuman Mati, Pelanggaran HAM dan Reformasi, Kompas, 25/2/2003

${ }^{22}$ Sebagian besar komisi yang pernah ada terfokus pada pengungkapan fakta, pengampunan baru diberikan setelah mendapat tekanan politik. 
paska Soeharto masih jauh dari harapan. Apa yang bisa dicapai dalam kurun waktu tersebut selain proses hukum minimal yang sudah berjalan, adalah menguatnya wacana dibentuknya Komisi Kebenaran dan Rekonsiliasi.Wacana itu kemudian diwujudkan oleh pemerintahan Megawati dengan merumuskan RUU KKR. Dasar hokum munculnya KKR di Indonesia tertuang dalam Tap V/MPR/2000 dan UU Peradilan HAM No. 26 Tahun 2000. Ketetapan MPR No. V/MPR/2000, pada tanggal 18 Agustus 2000 , tentang pemantapan persatuan dan kesatuan nasional, Bab I, Pendahuluan, huruf $B$, Maksud dan tujuan, alenia kedua, dan Bab V, Kaidah Pelaksanaan, yang masingmasing berbunyi sebagai berikut:

$\mathrm{Bab}$ l,huruf $B$, alenia kedua menegaskan bahwa "kesadaran dan komitmen yang sungguh-sungguh untuk memantapkan persatuan dan kesatuan nasional harus diwujudkan dalam langkah- langkah nyata, berupa pembentukan Komisi Kebenaran dan Rekonsiliasi Nasional, serta merumuskan etika berbangsa dan visi Indonesia masa depan". Dalam bab $V$, angka 3 juga ditegaskan bahwa "...Komisi ini (KKR) bertugas untuk menegakkan kebenaran dengan mengungkapkan penyalahgunaan kekuasaan dan pelanggaran hak asasi manusia pada masa lampau, sesuai dengan hukum dan peraturan perundang undangan yang berlaku, dan melaksanakan rekonsiliasi dalam perspektif kepentingan bersama sebagai bangsa. Lebih jauh dalam bab itu juga ditegaskan bahwa "Langkah-langkah setelah pengungkapan kebenaran, dapat dilakukan pengakuan kesalahan, permintaan maaf, pemberian maaf, perdamaian, penegakan hukum, amnesti, rehabilitasi, atau alternatif lain yang bermanfaat untuk menegakkan persatuan dan kesatuan bangsa dengan sepenuhnya memperhatikan rasa keadilan dalam masyarakat.
Undang-undang No.26 Tahun 2000 tentang Pengadilan HAM, Pasal 47 beserta penjelasannya menyatakan bahwa pelanggaran HAM yang berat yang terjadi sebelum berlakunya undang-undang ini tidak menutup kemungkinan penyelesaiannya dilakukan oleh Komisi Kebenaran dan Rekonsiliasi yang dibentuk dengan undangundang. Dalam penjelasan disebutkan bahwa KKR dimaksudkan untuk memberikan alternatif penyelesaian pelanggaran hak asasi manusia yang berat, yang dilakukan di luar pengadilan HAM.

Landasan hukum pembentukan KKR cukup jelas dan kuat, tetapi sayang ia tidak segera bisa terwujud sampai sekarang ini. Jika memperhatikan KKR di pelbagai Negara yang lahir segera setelah kekuasaan otoritarian berakhir, dan dikerangkakan sebagai upaya mewujudkan keadilan di masa transisi agar di era yang baru sudah tidak ada lagi sisa masalah, khususnya masalah pelanggaran hak asasi manusia, maka bagi Indonesia gagasan pembentukan KKR menjadi kehilangan momentum. Kalaulah 7 (tujuh) tahun paska kejatuhan Orde Baru masih dikerangkakan sebagai masa transisional, dan itu artinya KKR masih diperlukan, tetapi tersendatnya perjalanan RUU KKR belum juga disyahkan menjadi UU mengindikasikan tidak mudahnya perjuangan menyelesaikan pelanggaran berat HAM masa lalu itu.

Sejumlah spekulasi mengemuka bahwa terhambatnya RUU KKR terjadi akibat tekanan militer dan sisa-sisa elite politik lama yang tidak menghendaki sejumlah pasal yang mereka nilai bakal menyulitkan posisi mereka. Belakangan kecemasan akan nasib RUU KKR makin meninggi seiring dengan terpilihnya SBY sebagai Presiden serta tampilnya Golkar sebagai pemenang Pemilu yang menguasai Parlemen. Bahkan kekhawatiran lain mulai 
tertuju pada kemungkinan tidak berjalannya KKR sebagaimana menimpa sejumlah negara yang pernah memiliki KKR.

Pada akhirnya terpulang kepada pemerintahan SBY, apakah pemerintahannya kembali akan mewariskan pelanggaran berat hak asasi manusia masa lalu menjadi hutang pemerintahan setelahnya, sebagaimana dialami tiga presiden pendahulunya, yang berarti pula bahwa bangsa ini akan terus berada dalam situasi transisi yang tidak berkesudahan, Karena itu tugas dan tanggungjawab utama SBY dalam konteks ini dan sekarang ini adalah mementahkan hipotesis banyak kalangan bahwa latar belakang militer yang disandangnya akan membuatnya bersikap protektif terhadap bekas koorpnya. Jika saja hipotesis dari sebagian kalangan prodemokrasi itu benar, maka harapan adanya pengungkapan kebenaran pelanggaran berat HAM oleh rezim masa lalu dan pertanggungjawaban atasnya oleh rezim baru tidak akan terjadi, dan itu berarti pula bangunan demokrasi ditegakkan di atas pondasi yang amat rapuh yang potensial runtuh ditengah jalan.

\section{Penutup}

Pertanggungjawaban pelanggaran berat hak asasi manusia oleh rezim masa lalu merupakan agenda bagi setiap pemerintahan transisional karena disana terkandung hak untuk mengetahui kebenaran (rights to know the truth), hak atas keadilan (rights to justice), dan hak atas martabat manusia (rights to human dignity).Tugas pemerintahan transisi adalah menyediakan mekanisme bagi pertanggungjawaban rezim masa lalu, dan itu tidak hanya menjadi monopoli dari kewenangan yurisdiksi universal masyarakat internasional, tetapi juga menjadi kewajiban politik dan hukum setiap pemerintahan transisi.
Pilihan mekanisme pertanggungjawaban dapat dilakukan melalui proses hukum (penyelidikan, penyidikan dan penuntutan) atau melalui pengungkapan kebenaran. Masing-masing mekanisme memiliki kekuatan dan kelemahannya masingmasing, dan masing-masing model telah pernah dipraktikkan di pelbagai negara. Untuk kasus kejahatan perang dunia ke-ll, tentara Nazi Jerman dan Jepang telah digelar pengadilan Nurenberg dan Tokyo. Sementara model pengungkapan kebenaran telah dilaksanakan oleh lebih dari 20 negara. Salah satu yang terpenting adalah Komisi Kebenaran dan Rekonsiliasi (KKR) Afrika Selatan; Satu model KKR yang paling banyak dibicarakan dan menyita banyak perhatian masyarakat internasional.

Tugas utama komisi menurut Agung Putri $^{23}$; (1) mengungkap fakta, yaitu mengungkap kebenaran fakta yang harus mencerminkan kenyataan secara jelas dan jernih. Kebenaran harus bisa menjadi dasar untuk mengubah kebijakan yang mensponsori kekerasan masa lampau. Kebenaran yang manipulatif akan teruji, apakah demokratisasi berlanjut atau terhenti, (2) komisi diperlukan untuk menjelaskan tanggungjawab individu atas kekerasan masa lampau. Juga harus bisa mempertimbangkan bentuk pertanggungjawaban individu yang paling tepat, serta menjelaskan bagaimana pengampunan dapat diberikan, (3) komisi diperlukan untuk merumuskan posisinya di hadapan lembaga peradilan. Apakah menggantikan fungsi peradilan ataukah hanya sebagai pelangkap lembaga peradilan, dan (4) komisi diperlukan

${ }^{23}$ Agung Putri, Berjuang Mengungkap Kebenaran dan "Mengadili" Masa Lampau: Pengalaman Negeri Tertindas, dalam Ifdhal Kasim \& Eddie Riyadi Terre (d), Pencarian Keadilan di Masa Transisi, Elsam, 2003, hal. 197-198. 
untuk menjelaskan fungsinya dalam menyelesaikan trauma korban, keamanan korban dan kerugian yang dialami korban akibat kekerasan masa lampau.

Untuk mengakhiri tulisan ini saya kutipkan petuah O'Donnel dan Schmitter ${ }^{24}$ yang menyatakan:

"sukar untuk membayangkan bagaimana suatu masyarakat dapat berfungsi sampai suatu tingkat yang akan menghasilkan dukungan sosial dan ideologis bagi demokrasi politik jika tidak disertai dengan keberanian menyelesaikan bagian-bagian yang paling menyakitkan di masa lalu. Dengan menolak berkonfrontasi dan membebaskan diri dari kekuatankekuatan dan kebencian paling dalam, suatu masyarakat tidak hanya menguburkan masa lalunya, tetapi juga nilai-nilai etis paling dasar yang mereka butuhkan untuk menciptakan masa depan yang bergairah".
24 Agung Putri, Berjuang Mengungkap Kebenaran dan "Mengadili" Masa Lampau: Pengalaman Negeri Tertindas, dalam Ifdhal Kasim \& Eddie Riyadi Terre (d), Pencarian Keadilan di Masa Transisi, Elsam, 2003, hal. 197-198.

\section{Daftar Pustaka}

Agung Putri, Berjuang Mengungkap Kebenaran dan "Mengadili" Masa Lampau: Pengalaman Negeri Tertindas, dalam Ifdhal Kasim \& Eddie Riyadi Terre (ed),2003, Pencarian Keadilan di Masa Transisi,Jakarta: Elsam.

Diane Orentlicher: "Setting Accounts: The duty to Prosecute Human Rights Violations of a Prior Regime" in 100 Yale Law Journal, 1991.

Dianne F. Orentlicher, "Setting Accoubts: the Duty to Prosecute Human Rights Violation of A Prior Regime", The Yale Law Journal, Vol.100

Ifdhal Kasim(ed.),2003,Pencarian Keadilan di Masa Transisi, Jakarta:Elsam.

Ifdhal Kasim, dkk (ed),2001, Setelah Otoritarianisme Berlalu Esai-Esai Keadilan di Masa Transisi, Jakarta:ELSAM.

Karlina Laksono, Kompas, 19/8/2003

Laporan Amnesty International,1977, 'Torture in Greece: The First Torture's Trial:1975, London: Amnesty International.

Laurence Whitehead,1989, "The Consolidation of Fragile Democracies" in Robert Pastor, ed, Democracies in the Americas: Stopping the pendulum, New York:Holmes and Meier.

Martin Meredith,1999, Coming to Terms, New York: Public Affairs. 
Mengungkap Kebenaran Pelanggaran Berat HAM Masa Lalu...; Suparman Marzuki

Priscilla B. Hayner,2002, Mencari akar dan Pandangan Bersama, Studi Banding Lima Belas Komisi Kebenaran di Berbagai Negara (terjemahan), Jakarta:ELSAM

Robert K. Goldman,1993, Amnesty Laws and International Law: A Specific Case (International Commission of Jurist, Prosiding).
Samuel Huntington,1991, Third Wave: Democratization in the late Twentieth Century, University of Oklahoma Press.

Thomas Sunaryo, Kompas, 25/2/2003 